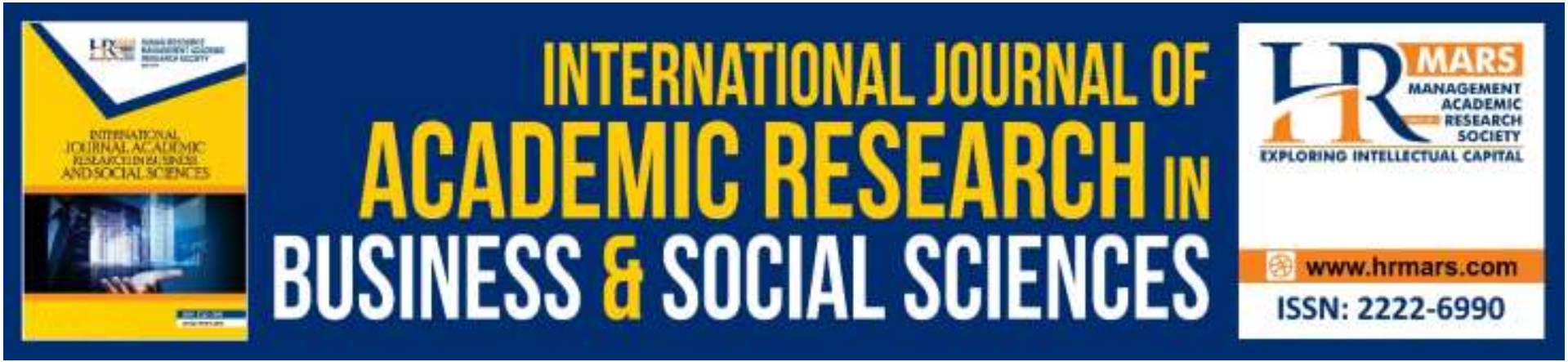

\title{
Integrative Approaches towards Immigrants: A Sample from a District of Istanbul
}

\author{
Orhan Kocak, Eymen Ekmen, Serkan Eti
}

To Link this Article: http://dx.doi.org/10.6007/IJARBSS/v9-i9/6299

DOI: $10.6007 /$ IJARBSS/v9-i9/6299

Received: 04 July 2019, Revised: 12 August 2019, Accepted: 02 September 2019

Published Online: 24 September 2019

In-Text Citation: (Kocak, Ekmen, \& Eti, 2019)

To Cite this Article: Kocak, O., Ekmen, E., \& Eti, S. (2019). Integrative Approaches Towards Immigrants: A Sample From A District Of Istanbul. International Journal Of Academic Research In Business And Social Sciences, 9(9), 334-347.

\section{Copyright: (c) 2019 The Author(s)}

Published by Human Resource Management Academic Research Society (www.hrmars.com)

This article is published under the Creative Commons Attribution (CC BY 4.0) license. Anyone may reproduce, distribute, translate and create derivative works of this article (for both commercial and non-commercial purposes), subject to full attribution to the original publication and authors. The full terms of this license may be seen at: http://creativecommons.org/licences/by/4.0/legalcode

\section{Vol. 9, No. 9, 2019, Pg. 334 - 347}




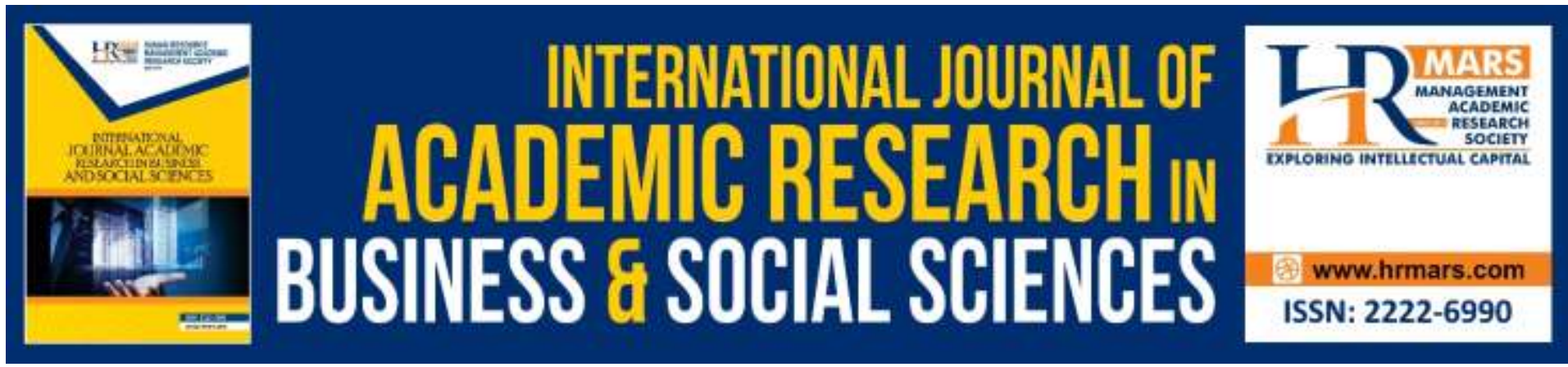

\title{
Integrative Approaches towards Immigrants: A Sample from a District of Istanbul
}

\author{
Orhan Kocak
}

Istanbul University Cerrahpaşa, Faculty of Health Science, Department of Social Work

\section{Eymen Ekmen}

Istanbul Arel University, Faculty of Health Science, Department of Social Work

\author{
Serkan Eti \\ Istanbul Medipol University
}

\section{Abstract}

This study analyses the socio-economic situations being contended with the Syrian immigrants living in Beylikduzu district in Istanbul in terms of the analytic and industrial circumstances. This paper exposes the immigrants' economic problems being interlaced with the education and Turkish language. To guide the analysis and interpretation of the quantitative data in this research, a random sampling was conducted to the Syrian immigrants. This survey is divided into two parts: (1) questions relative to the demographic status (age, gender, job, education and place); and (2) questions regarding the socio-economic exigency (labor markets, wage satisfaction, working hours, challenges in learning Turkish, accommodation possibilities and psychological needs) of the Syrian settlers. This study arrives at the following findings: Syrian immigrants are working with long working hours and low wages; Syrian families have been subjected many challenges such as shelter, basic food and basic goods; and Syrian migrants' increasing number of accommodation problems. In conclusion, Syrian immigrants have an inconceivably wide range of problems from socio-economic to languages. However, these problems are not considered as hinders to achieve equality, equity, and social justice which everyone deserves.

Keywords: Asylum-seeker, Syrians, Immigrants' Problems, Beylikduzu

\section{Introduction}

Turkey have taken immigrants who coming from Central Asia and Middle East countries such as Afghanistan, Pakistan, Iraq and Syria. In general, with the conflicts in Asia, and in specifically with a civil war in Syria, the number of the immigrants have 
been coming to Turkey is increasing every year. Especially, since the beginning of civil war in 2011 in Syria, Turkey has been a place for immigrants who have been fleeing from conflicts in Syria and majority of these immigrants want to move from less developed and small cities to developed and big cities such as Istanbul, Ankara, Gaziantep and Izmir. This immigration not only changes the population in these cities but also affecting the infrastructures, health and education services, and labor markets in Turkey. Even, there are some cities where the population of immigrants is higher than native citizens. After that situation, Turkey's Government and people have faced many difficulties. The effects of the increasing immigrant population in Turkey, both economically and socially, are being felt not only by Turkish state but also by people. Political, economic, social and cultural difficulties forced the government to take some legal and institutional measures on national level. Central government, local governors and municipalities have been working on the issue by trying to integrate these people into the daily life of Turkey. In this context, it is aimed to investigate the problems, living conditions, family situations, economic and educational status of immigrants living in Turkey.

Beylikduzu is a district of Istanbul and Beylikduzu Municipality has some services and projects for the immigrants live in the district in order to support their daily life and integrate them into the Turkish Society. The Municipality gives the aid to the immigrants in cash and in kind, and help them to find jobs, homes and household stuff. Referral services are offered if immigrants are needed to be directed to another place or institution, they are all informed and directed to those places. Also, psychological support services are given to individuals and families of immigrants, and enrolling to the schools are offered by the Municipality for the immigrants' families by informing how to enrol their children who are in school age and don't go to school. In this study, all these services will be evaluated in the context of local administration and social work. In addition, the survey was implemented with 150 immigrants to understand their socioeconomic status, education level, the access to the labor market and the problems they faced and their access to some basic needs will be evaluated.

\section{Immigration}

Immigration; can be defined as leaving from a place, where the individuals or communities used to live, to another place with some reasons and temporarily or permanently. In this sense, immigration has been going on since the beginning of humanity. It is possible to classify the immigration according to many different criteria such as reasons, purposes and boundaries. For example, immigration can be classified in terms of causes; natural, political, social and economic; in terms of boundaries, internal immigration and external immigration; in terms of aim, working and asylum (Icduygu \& Sirkeci, 1999, p. 249).

With another classification, immigration can be explained under the two general headings as compulsory and voluntary. Compulsory immigration is defined as when people have to leave their places of residence for the reasons such as natural disasters, wars and exiles. When people leave their places with their own wishes for the purpose of achieving better living conditions is defined as voluntary immigration (Yilmaz, 2014, p. 1687). Different definitions can be made by different perspectives. 
From another point of view, compulsory immigration is defined as placing some people for some reasons by the government either directly or indirectly (Polian, 2004, p.1). The extent of immigration can vary depending on the type of immigration. The quantitative of immigration is important in the dimension of impact. Major mass immigration movements can be seen in the cases of compulsory immigration such as war, natural disaster and internal conflicts (Li \& Frieze, 2012, pp.5-7).

\section{The Reasons of Immigration}

There are many reasons why people immigrate. Some of these reasons are; unemployment, poverty, working conditions, natural disasters, wars, political events, marriage, income injustice and internal conflicts. In the last two decades, the number of immigrants in the world has increased. Globalization is also one of the reasons and factors that increase the number of immigrants and the irregular increase has been an effect on the formation of irregular immigration (Yilmaz, 2014, pp. 1688-1689).

Immigration is often experienced from underdeveloped and developing countries to developed countries or from underdeveloped countries to developing countries. In underdeveloped countries, people are experienced with the difficulties and problems such as the lack of adequate employment opportunities for the growing population, the inability to get adequate services, political instability, internal disturbances and wars, and the lack of education and health services. Because of these issues, people of the underdeveloped countries try to immigrate to the countries where there are many economic, social, cultural opportunities and high level welfare services. Moreover, the majority of host countries' population is getting older, that's why they need young labor force in every sector as well as social and welfare services. In a study of Jivorsky and his colleagues, was done with African immigrants, although immigrant workers face language barriers and some problems they experience, they still want to immigrate for the reasons of better education, better working conditions, social life, economic reasons, better health services and etc. (Jirovsky et al., 2015, p. 9).

\section{Immigration Movements to Turkey}

Considering immigration movements to Turkey, it is possible to talk about many immigration movements from the time of the declaration of the Republic until the present day. Firstly, it can be mentioned Mutual Turkish-Greek exchange between 1922 and 1938. When considering other important immigration movements, it is possible to mention about the immigrations were realized in 1924, 1936 and 1953 from Balkans to Turkey. Another wave of immigration is the one which went on till 1989 from Bulgaria to Turkey. Except these immigration waves, it is possible to mention about the immigrations were realized from different countries after 1979 Iranian Revolution, 1988 Iraq-Halabja Massacre, 1991 Iraq-Gulf War, 1995 Srebrenica Massacre, 1999 Events in Kosovo, 1982 Soviet Invasion of Afghanistan, 2003 AmericaIraq War and ongoing Syrian Civil War (Goc Idaresi Genel Mudurlugu, 2015).

\section{Arab Spring, Syria and Intensive Immigration to Turkey}

The anti-government protests on December 17, 2010 spread rapidly, and the popular uprising that took place in 2011 with the influences of Arab countries such as 
Egypt, Libya, Syria, Yemen, Algeria and Jordan is called "Arab Spring". Behind the Arab Spring, there are many factors such as administrative problems, trust between the people and power, political causes, historical reasons, social reasons, injustice in income distribution and living economic troubles (Memiş, 2015, pp. 101-102).

This process, called the "Arab Spring", has not affected every country in the process at the same time. In some countries it caused changes in power and regime, but in some countries it led to internal confusion and civil war. Arab Spring, which had its effect on 15 March 2011 in Syria, has transformed into civil war and an international crisis over time, and since that day, immigrations to neighbouring countries and the whole world have begun intensively from Syria. Immigrations have still been continuing in the 7th year of the war. The countries most affected by this wave of immigration are Syria's neighbours, Turkey, Jordan and Lebanon (Memiş, 2015, ss.102-103). It is known that there are more than 3 million Syrian immigrants in Turkey with an unregistered population. After Turkey, the distribution of Syrian immigrants to the countries is respectively; Lebanon, Jordan and Iraq (Ortak, 2016).

Before Arap Spring Period and Syrian Civil War, Turkey has taken a number of immigration from the Balkans and some other countries such as Afghanistan, China (Uygur Turks), Iran and Iraq. After the Iraq - American War in 2003, there have been immigrations from Iraq to Turkey. Moreover, due to the internal disturbances that have been in the country for many years, there have been immigrations from Afghanistan to Turkey. After the immigration, the immigrants have settled to all of the provinces of Turkey but especially they have settled in Istanbul as intensively (Dogan \& Karakuyu, 2016, pp. 304-305).

When the immigration issue is addressed; the person, the family, the place of origin, the place of immigration, the causes, the results and the effects of it should be considered in a broad perspective. When viewed from a broad perspective, it appears that immigration is really an important issue and affects a wide area (Kocak \& Gunduz, 2016, p. 67). It is also important to be known the characteristics of origin countries and the culture of the immigrants by the societies and officials at the place where they go. By doing that, many problems of the immigrants resulting from cultural, religious, traditional and lifestyle will be able to solve and the empathy with them will be done easily (The Economist, 2016).

\section{Immigration's Effects and Immigrants' Problems}

Immigration is a long process when considering the effects it is both a negative and a positive phenomenon. According to Kane; it does not matter whether the immigration is the result or cause and whatever their purpose, there will be many effects of immigration such as economic, political, social etc. (1995). Immigration has effects on both immigrant and immigration countries' institutions and people (Kocak et al., 2017, 65). This process has in two ways effect which means two sides of immigration in the country of origin and country of host. Also, citizens of origin countries invest in their own countries, even if they live in another country. Not only they bring money but also their experiences, cultures and habits they gained in the countries they had lived in when they return to their countries. Regardless of whether the immigration is compulsory or voluntary, the effects can change as positive and negative on the country where immigration is experienced. For this reason, as Borjas 
says; it is an issue that must be dealt with many ways to overcome, and some things must be foreseen in advance (1994, p. 1914). In addition to some adverse effects such as adaptation problem, cultural conflict, language problem and security problem in the immigrated country, there are positive effects such as increase of young workforce, sharing of different experiences, cultural wealth and new economic investments for the development of the host country (Yilmaz, 2014, pp. 1629-1696). Besides the effects of immigration on the countries, there are many effects of immigration on the people as well. Immigrants may face problems such as exclusion, integration problems, language problems, health problems and economic problems in countries where they live (Burgess, 2004; Fuller, 2002: 5).

\section{Language Barrier and Social Exclusion}

One of the most basic problems that immigrants face is language barrier. When the language of the immigrated country is not known, it can become a big obstacle for integration daily life. Due to not overcoming the language barrier, immigrants can face with other problems such as education, transportation, health, socialization and finding a job (Snyder, 2006: 50).

It is known that one of the groups that overcome the language barrier earliest is children and that's why they can be integrated easily. Children can take an active role in the family and society, while parents can't take an active role until they exceed the language barrier. This can lead to changes in roles and create other problems within the family (cited by Terzioglu, 2008, p. 241); (quoted by Franz, 1981, p. 58). Therefore, the language barrier has a great importance for immigrants. Language education is an indispensable element not only for the immigrants but also for the society of the country which has accepted the immigrants.

Social exclusion is a very important issue in today's world. Social exclusion has gained momentum with the globalization (Kavi, Kocak, 2010, 225). Especially immigrants are the most socially excluded group around the globe (Kocak \& Gunduz, 2016, p. 72). Socially excluded people or group will be prevented access to some or all of the rights necessary for the integration of a different group within a society and will be left out of society. Immigrants have an important place among the groups that are subject to social exclusion because of the systematic obstruction of their access to certain rights. The problems of integration, cultural diversity and inability to speak the same language can increase social exclusion. Social exclusion and access to rights can vary depending on the immigration policies and dynamics of the specifically experienced country (Dedeoglu, 2011, pp. 29-31). The fact that individuals who have suffered from social exclusion and have difficulties in participating in social life, should benefit from education services, vocational and host country's language training, health and transportation services, involvement in employment and labor life, access to goods and services, acquisition of housing and participation in cultural activities (Kavi, Altun, 2010, 451).

\section{Health and Economic Problems}

Immigration is known to have negative effects on mental health because it is a difficult process (Sir \& Bayram \& Ozkan, 1998, p. 87). In addition, in order to benefit from the health of immigrants in any health problems other than mental health 
problems, they must be encouraged to register in the insurance system of host country and be insured. Immigrants, even if they are legally entitled to all these rights, may have problems accessing health services due to the reasons such as their poor economic status, the foreign language inability, legal status and procedures (Aksu \& Sevil, 2010, p. 136). But, the immigrants under temporary protection in Turkey can benefit from the health care services free of charge. They can go to hospitals and to health institutions and get free treatment in Turkey.

Immigrants, who come with forced immigration, mostly escape in an urgent way from their country or the country they lived in the past. That's why; they come with a lot of loss material and loss spiritual in this difficult process. Even if they have status and good income in their own country, they may lose them also in the country where they migrate. They may have difficulty in finding jobs in the country they migrate to or they can be employed at low wage rates even if they find work. This causes immigrants to face with economic problems (Ustubici, 2011, pp. 2-12).

\section{Education and School Problems}

One of the problems of immigrants faced is education and school problems. The Convention on the Status of Refugees states that the countries will apply the same procedure for refugees as they do to their citizens on basic education. Due to the differences in language and education system, refugees and immigrants may experience difficulties on education and training in the countries where they migrate. Moreover, if immigrants have to leave education before graduation, they can face with problems about continuity of the education in the country where they migrate. Even if immigrants are graduated, they can still face problems with equivalence in diplomas in the country where they migrate. Syrian refugees have the right to attend primary and secondary education as free of charge in Turkey (Saleh, A, Aydin, S. \& Kocak, O., 2018, p. 448).

\section{Data Collection and Sampling}

This work is carried out with 150 immigrants living in Beylikduzu in Istanbul. According to the official municipal records, there are 3000 registered immigrants living in Beylikduzu which has 297.420 populations. For this population, at least 93 observations or immigrants at $95 \%$ confidence level are required for the sample adequacy (Özdamar, 2004). In order to exceed this number and get adequate number of sample, this study was done with 150 people. Within the scope of the study, a questionnaire of 22 questions including demographic information is applied to immigrants as well as 12 questions with 5 -Likert scale in the survey.

According to the data, the average age of 150 people participating in the study is 26,26 . The number of the male immigrants in the data is lower than female since female immigrants come to the social services center to mention their needs or take their support. In this sense, 92 of the immigrants are female and 58 of them are male. Only 8 of the immigrants are students and 36 of them are working. When it is looked to the number of individuals in households, 14 families have 3 or fewer individuals, 55 families have 4 or 5, 56 families have between 6 and 7, and 25 families have 8 or more members. 
When the educational status is examined, 15 of the immigrants are not literate, 61 of them are primary school graduates, 28 of them are secondary school graduates, 31 of them are high school graduates and 15 of them are undergraduate level or graduates. While 137 of the immigrants live in rents, 11 of them are staying in a place which is free and only 2 of them declared that they have their own house. While $75.3 \%$ of immigrants stated that they work in a low payment business, the average income of a migrant family is calculated as 1458 ₹ and the average income of the individual is $477 €$. It is observed that 18 of the 37 working migrants are working between 8 and 10 hours in a day and 13 of them are working more than 10 hours in a day. It is also found that 33 of the 37 migrant workers are working 6 days or all days in a week.

Table 1: Frequencies of Demographic Variables

\begin{tabular}{|c|c|c|c|}
\hline & Variables & Frequency & Percent \\
\hline \multirow{8}{*}{ Age } & -15 & 7 & 4,67 \\
\hline & $16-18$ & 21 & 14,00 \\
\hline & $19-25$ & 40 & 26,67 \\
\hline & $26-30$ & 46 & 30,67 \\
\hline & $30-40$ & 28 & 18,67 \\
\hline & $40-50$ & 4 & 2,67 \\
\hline & $60-65$ & 3 & 2,00 \\
\hline & $65+$ & 1 & 0,67 \\
\hline \multirow{2}{*}{ Gender } & Man & 58 & 38,67 \\
\hline & Female & 92 & 61,33 \\
\hline \multirow{3}{*}{ Job } & Employee & 36 & 24,00 \\
\hline & Unemployed or Housewife & 106 & 70,67 \\
\hline & Student & 8 & 5,33 \\
\hline \multirow{6}{*}{ Education } & Not literate & 15 & 10,00 \\
\hline & Primary school graduates & 61 & 40,67 \\
\hline & Secondary school graduates & 28 & 18,67 \\
\hline & High school graduates & 31 & 20,67 \\
\hline & Undergraduate & 12 & 8,00 \\
\hline & Advanced education graduates & 3 & 2,00 \\
\hline \multirow{3}{*}{ Place } & Rent & 137 & 91,33 \\
\hline & Free place & 2 & 1,33 \\
\hline & Own house & 11 & 7,33 \\
\hline
\end{tabular}

According to this demographic information, immigrants in Beylikduzu are young and great majority of them are unemployed. The high unemployment level of immigrants and the low level of education of working people are important problems for the immigrants. Because these issues trigger other problems such as social, health, integration and economic, unemployment and education should be taken into consideration. While a large proportion pays rent for their home, the monthly income of an immigrant family is about at the minimum wage level of Turkey. Considering that the average income is 477 of an individual, it can be said that 3 people work in each family averagely. In this sense, 3 individuals should work in every immigrant family in 
order to get an income which becomes equal to the minimum wage level of Turkey. As for working conditions in terms of wage and working duration, they declare that they are working in irregular, part-time, unsecure jobs and most of them spend 6 or more per week working more than 8 hours a day on average.

\section{Survey Analysis}

Likert-scale questions were directed towards the problems of immigrants in the continuation of the study. Factor analysis has been used for this part of the study. By putting together the related questions by factor analysis, fewer new dimensions were found. Briefly, factor analysis is a method of dimension reduction by which analysis of basic components is used (Costello \& Osborne, 2005). Accordingly, three main problems have been identified in the factor analysis conducted in accordance with the participants' answer: Shelter, basic goods, and food problems. The value of the KMO (Kaiser-Meyer-Olkin Measure of Sampling Adequacy) of the factor analysis is 0,608 and it can be said that the analysis is significant because it is larger than 0,50 (Kaiser, 1974). In addition, the total explained variance of the analysis is $70,655 \%$. The results of the factor analysis are given in Table 2.

According to the results of factor analysis, all loads are over 0,40 . The reliability and validity of three dimensions are also examined. If the AVE value is greater than or equal to 0,50 , it indicates validity and if the CR value is greater than or equal to 0,60 , it indicates the reliability of the dimension. Also, if the CR value is greater than or equal to 0,80 , it indicates a high level of reliability of the dimension (Hair, Hult, Ringle, \& Sarstedt, 2014). The AVE values of three dimensions are above 0,50 . As the $C R$ values of the two dimensions obtained by factor analysis are higher than 0,80 , two of the dimensions are high-level reliability and only the food problem dimension is medium reliable.

Table 2. Results of Factor Analysis

\begin{tabular}{|c|c|c|c|}
\hline & $\begin{array}{l}\text { Factor } \\
\text { Loading }\end{array}$ & AVE & $\mathrm{CR}$ \\
\hline \multicolumn{4}{|l|}{ Factor 1: Shelter Problem } \\
\hline The place we are staying is too small. & 0,886 & \multirow{3}{*}{0,73} & \multirow{3}{*}{0,84} \\
\hline The conditions we live are too bad. & 0,823 & & \\
\hline \multicolumn{2}{|l|}{ Factor 2: Basic Goods Problem } & & \\
\hline We need household goods. & 0,829 & \multirow{2}{*}{0,68} & \multirow{2}{*}{0,81} \\
\hline $\begin{array}{l}\text { We cannot meet the need for clothing. } \\
\text { Factor 3: Basic Food Problem }\end{array}$ & 0,826 & & \\
\hline We need diaper/milk. & 0,826 & \multirow{2}{*}{0,58} & \multirow{2}{*}{0,73} \\
\hline We need food / dry food. & 0,687 & & \\
\hline
\end{tabular}

The relationship between the three dimensions is examined. According to the results of correlation analysis, a statistically significant relationship was not found between the basic food and the basic goods problems. Relations outside of it are statistically significant. It can also be said that the dimensions provide the discriminant validity with the correlation matrix. Because the correlation coefficient values with 
each other are smaller than root of the AVE values of the dimensions (Hair, Hult, Ringle, \& Sarstedt, 2014).

Table 3: Correlation Matrix and Square Root of AVE

\begin{tabular}{lccc}
\hline & Shelter Problem & $\begin{array}{c}\text { Basic Goods } \\
\text { Problem }\end{array}$ & $\begin{array}{c}\text { Basic Food } \\
\text { Problem }\end{array}$ \\
\hline Shelter Problem & 0,85 & & \\
\hline Basic Goods Problem & $0,275^{* *}$ & 0,82 & \\
\hline Basic Food Problem & $0,192^{* *}$ & 0,144 & 0,76 \\
\hline$*<0.05$ & &
\end{tabular}

All the values in the correlation matrix are positive, and the problems are significant, and they are in the same direction, except between goods and food. Therefore, it can be said that if the shelter problem increases, other problems will be increased. Similarly, there is relation between basic food and shelter problem. So, the more immigrants have basic food problems, the more they have shelter problems. It can be said that, if they could not meet their food needs, they could not meet their need for shelter.

The averages of these dimensions are 2,59, 2,03 and 3,53, respectively. According to this, it seems that the basic food problems of migrants take priority. In this sense, we may think that they need food / dry food and diaper/milk and it is seen as a prior problem. The problems of immigrants have been examined according to demographic information, and ANOVA analysis and T-tests was used for this purpose. These are analysis' that tests whether two or more two groups have the same average (Armutlulu, 2008).

According to the T-tests, the food problem was statistically different in terms of gender (p-value 0,013$)$ and it was found that women (mean of women 3,68 ) have more food problems than men (mean of men 3,29).

Table 4: T-Tests between Genders

\begin{tabular}{|c|c|c|c|c|}
\hline Variable & Groups & Mean & Std. Deviation & p \\
\hline \multirow{2}{*}{ Shelter Problem } & Men & 2,5776 & 1,08337 & \multirow{2}{*}{0,906} \\
\hline & Women & 2,5978 & 0,97281 & \\
\hline \multirow{2}{*}{ Basic Goods Problem } & Men & 2,0862 & 0,90388 & \multirow{2}{*}{0,538} \\
\hline & Women & 2,0000 & 0,78446 & \\
\hline \multirow{2}{*}{ Basic Foods Problem } & Men & 3,2931 & 1,02184 & \multirow{2}{*}{0,013} \\
\hline & Women & 3,6848 & 0,86035 & \\
\hline
\end{tabular}

Similarly, those who say that they do not work in an income-generating business (mean 3,69 ) are statistically significant and more likely to have food problems than those in income-generating jobs (mean 3,07 ). 
Table 5: T-tests Between Work Status

\begin{tabular}{ccccc} 
Variable & Groups & Mean & Std. Deviation & $\mathbf{p}$ \\
\hline \multirow{2}{*}{ Shelter Problem } & Yes & 2,351 & 0,781 & \multirow{2}{*}{0,099} \\
& No & 2,668 & 1,070 & \\
\hline \multirow{2}{*}{ Basic Goods Problem } & Yes & 1,919 & 0,722 & \multirow{2}{*}{0,336} \\
& No & 2,071 & 0,863 & \multirow{2}{*}{$\mathbf{0 , 0 0 0 0}$} \\
\hline \multirow{2}{*}{ Basic Foods Problem } & Yes & 3,068 & 1,008 & \\
& No & 3,686 & 0,872 & \\
\hline
\end{tabular}

According to the ANOVA analysis, shelter and goods problems differ statistically according to the way they meet their nutritional needs ( $p$-Value $<0,000$ ). Migrants who are helping out with nutrition needs from social assistance agencies or non-governmental organizations (mean of shelter problem 4,33, mean of goods problem 3,17) have more shelter and goods problems than others (mean of shelter problem 2,48, mean of goods problem 1,96). These institutions usually provide financial assistance, which is only sufficient for basic food needs, indicating that there is no solution to shelter and basic goods problems.

Table 6: ANOVA Between Fulfillments of Needs

\begin{tabular}{|c|c|c|c|c|}
\hline Variable & Groups & Mean & Std. Deviation & $\mathbf{P}$ \\
\hline \multirow[t]{5}{*}{ Shelter Problem } & With Working & 2,569 & 0,870 & \multirow{5}{*}{0,000} \\
\hline & Saving & 2,125 & 1,094 & \\
\hline & Neighbor & 2,417 & 0,970 & \\
\hline & Social Assistance & 4,333 & 0,612 & \\
\hline & Support From Goverment & 2,363 & 1,019 & \\
\hline \multirow[t]{5}{*}{$\begin{array}{l}\text { Basic Goods } \\
\text { Problem }\end{array}$} & With Working & 1,879 & 0,682 & \multirow{5}{*}{0,000} \\
\hline & Saving & 1,563 & 0,904 & \\
\hline & Neighbor & 2,500 & 1,265 & \\
\hline & Social Assistance & 3,167 & 0,750 & \\
\hline & Support From Goverment & 2,138 & 0,840 & \\
\hline \multirow[t]{5}{*}{$\begin{array}{l}\text { Basic Foods } \\
\text { Problem }\end{array}$} & With Working & 3,534 & 0,831 & \multirow{5}{*}{0,177} \\
\hline & Saving & 3,188 & 1,580 & \\
\hline & Neighbor & 3,333 & 1,080 & \\
\hline & Social Assistance & 4,222 & 0,870 & \\
\hline & Support From Goverment & 3,475 & 0,987 & \\
\hline
\end{tabular}

\section{Discussion and Conclusion}

Complete integration of the immigrants is an important issue to sustain the stability and a sense of proximity to the host country. Also, approval to move or travel to other cities will reduce the high-level accumulation of the immigrants in the cities 
which are very near to the Syria and Iraq. In order to integrate these immigrants, working opportunities should be offered to them. In this sense, all host countries must give opportunities to Syrian immigrants in order to empower as the vulnerable population. Turkey is one of these countries; it offers employment opportunities whether it is formal or informal, as well as free health and education services. Additionally, countries who accept Syrian immigrants must allow being used the Syrian credential such as certificates and other school diplomas as an evidence of work history and qualification. By using the experiences and qualifications of immigrants in host countries, the capacity of immigrant people will not be wasted. Moreover, the host country will provide an extra labor force to strengthen their economy and production ability, and also the troubles in host countries such as social payments, instability among people, the burden on governments, and integration problems will be reduced. In this way, not only harmonization and integration issues of the immigrant will be decreased but also the empowerment process of immigrants will be started. And then, immigrants' socioeconomic conditions will be better as well as their social, emotional, mental and physical health. Beylikduzu Municipality has some services and projects for the immigrants live in the district in order to support their daily life and integrate them into the Turkish Society. The Municipality gives the aid to the immigrants in cash and in kind, and helps them to find jobs, homes and household stuff. Referral services are offered if immigrants are needed to be directed to another place or institution, they are all informed and directed to those places. Also, psychological support services are given to the individuals and families of immigrants, and enrolling to the schools are offered by the Municipality for the immigrants' families by informing how to enrol their children who are in school age and don't go to school.

Syrian immigrants who are living in Beylikduzu have many problems. Especially they have economic problems as well as education and Turkish language. With this research, it is found that Syrian immigrants are working with long working hours and low wages. In order to make their living, it is seen that at least 3 members in each Syrian family are working or have to work. Despite the working of majority of family members, Syrian families have been subjected many challenges such as shelter, basic food and basic goods. According to the survey, it can be said that these issues are interrelated and triggers each other. It is possible to say that the common point behind this relationship is the economic situation. Due to economic problems, food problems will also increase with the increasing number of accommodation problems of Syrian immigrants. The increase in economic problems will also have a further effect on other problems. Women especially have basic goods problems. This is seen as a striking problem because the women are generally interested in housework and the men are usually going to the working. Similarly, there is a relationship between working conditions and the basic goods problem. In this sense, it can be said that immigrants who do not work have more problems in terms of basic goods than working immigrants. Syrian immigrants have expressed that they meet their needs in different ways. They can meet their needs by working, getting help from charities, using their old savings, getting help from their neighbours, receiving support from the government, municipalities and non-government organizations. 
Some figures can be inferred from research. A great majority of immigrants (96\%) think that reaching labor markets is too difficult for them, $93 \%$ of females and $35 \%$ of males are not working or unemployed, more than $75 \%$ are not satisfied with their wages, majority is working more than 8 hours daily and more than 6 days weekly, $90 \%$ of immigrants have difficulties in learning Turkish language, $41 \%$ says they need psychological support and $42 \%$ indecisive for their psychological situation, $91 \%$ of them are paying their rent for their home, more than $90 \%$ complains that rent prices is very high, and more than $95 \%$ of immigrants have difficulties in daily life because of the language problem.

\section{References}

Aksu, H., Sevil, V. U. (2010). Goc ve kadin sagligi. Maltepe Universitesi Hemşirelik Bilim ve Sanati Dergisi,2(3), 133-138.

Armutlulu, I. H. (2008). Işletmelerde Uygulamali Istatistik. Istanbul: Alfa Basim Yayim Dagitim Ltd. Şti.

Borjas, George, J. (1994), "The Economics of Immigration", American Economic Assocation, Vol. 32, N.4, pp. 1667- 1717.

Burgess, A. (2004). Health challenges for refugees and immigrants. Refugee Reports, 25(2), 1-3

Cesur-Kilicaslan, S. and Terzioglu, R. (2008). The effects of immigration and emigration on the family structure in Turkey. The International Journal of the Humanities, 6(1), 240-244.

Costello, A. B., \& Osborne, J. W. (2005, July). Best Practices in Exploratory Factor Analysis: Four Recommendations for Getting the Most From Your Analysis. Practical Assessment, Research \& Evaluation, 10(7), 1-9.

Dedeoglu, S. (2011). Turkiye'de gocmenlerin sosyal dişlanmasi: Istanbul hazir-giyim sanayinde calişan Azerbaycanli gocmen kadinlar ornegi. Ankara Universitesi SBF Dergisi, 66(1), 28-48.

Dogan, B., Karakuyu, V. M. (2016). Suriyeli gocmenlerin sosyoekonomik ve sosyokulturel ozelliklerinin analizi: Istanbul Beyoglu ornegi. Marmara Cografya Dergisi, 33, 302-333.

Franz, A. B. (1981). Thesen zur Problematik einer interkulturellen Erziehung, in: (Hrsg.) H.Essinger-A.Hellmich-G.Hoff: Auslanderkinder im Konflikt, Athenaum Ver. Konigstein. (Turan, K. (1997). Almanya'da Turk Olmak. Ankara:T.C.Başbakanlik Aile Araştirma Kurumu Yayinlari'ndan Alinmiştir).

Fuller, T. (2002). "Foreign Workers Face Turning Tide: Backlash in Europe", in International Herald Tribune, 24.12.2002

Mudurlugu, G. I. G. (2015). Erişim tarihi: 25 Aralik 2017, http://www.goc.gov.tr/icerik3/kitlesel-akinlar_409_558_559

Hair, J. F., Hult, T. G., Ringle, C. M., \& Sarstedt, M. (2014). A Primer on Partial Least Squares Structural Equation Modeling (PLS-SEM). United States of America: SAGE.

Icduygu, A., Sirkeci, V. I. (1999). Cumhuriyet donemi Turkiye'sinde goc hareketleri. O. Baydar (Ed.), 75 yilda koylerden şehirlere (ss.249-268). Numune Matbaasi: Tarih Vakfi Yayinlari.

Kaiser, H. F. (1974, Mart). An Index Of Factorial Simplicity. Psychometrika, s. 31-36. 
Kane, H. (1995). Leaving home. Society, 12(4), 10-16.

Ersin, K., Serdar, A. (2010), Sosyal Icerme Acisindan Eski Hukumlulerin Girişimcilige Yonlendirilmesi ve Denetimli Serbestlik Faaliyetleri, 2.Uluslararasi Trakya Bolgesel Kalkinma ve Girişimcilik Sempozyumu, 1-2 Ekim 2010, Igneada/Kirklareli, s.449-461.

Ersin, K., Orhan, K. (2010) , Kureselleşmenin Sosyal Dişlanmaya Etkisi ve Uluslararasi Calişma Orgutu Normlari, 3. Uluslararasi Kureselleşme Surecinde Kafkasya ve Orta Asya Kongresi, 15-17 Ekim 2010, Baku.

Kocak, O., Gunduz, V. R. (2016). Avrupa Birligi goc politikalari ve gocmenlerin sosyal olarak icerilmelerine etkisi. Yalova Sosyal Bilimler Dergisi, 7,66-91.

Kocak, O., Keskin, A. \& Yildiz, H. (2017). Suriyeli Gocmenlerin Turkiye Emek Piyasasina Etkileri ve Yalova Ornegi, Route Educational and Social Science Journal Volume 4(3), April 2017, ss. 59-74.

$\mathrm{Li}, \mathrm{M}$. and Frieze, I. (2012), "Before the big decision: Psycological theories on premigration motivation", Immigration polisicies, challenges and impact (Ed. E. Tartakovsky). Nova Publishers, 3-27.

Memiş, H. (2015). Ic savaş nedeniyle Kilis'te yaşayan Suriyelilerin oluşturdugu sosyoekonomik algilar uzerine bir araştirma. Elektronik Sosyal Bilimler Dergisi, 14(52), 100-114.

Ozdamar, K. (2004). Paket Programlar ile Istatistiksel Veri Analizi. Eskişehir: Kaan Kitabevi.

Polian. P. Against Their Will: The History and Geography of Forced Migrations in the USSR. Budapest: CEU Press. 2004

Saleh, A., Aydin, S. \& Kocak, O. (2018). A comparative study of Syrian refugees in Turkey, Lebanon, and Jordan: Healthcare access and delivery. OPUS International Journal of Society Researches, 8(14), 448-464. DOI: 10.26466/ opus. 376351

Sir, A., Bayram, V. Y., Ozkan, V. M. (1998). Zoraki ic gocun ruh sagligina etkileri uzerine bir on calişma. Klinik Psikiyatri Dergisi, 1(2), 83-88.

Ortak, S. (2017). Erişim tarihi: 06 Haziran 2017, https://www.stratejikortak.com/2016/04/suriyeli-multecilerin-sayisi.html, online 25.07.2018.

Snyder, Diane, L. (2006). The New "Integration" Tests and Materials in the Netherlands, Germany, Baden-Wurttemberg, and the United Kingdom: The Muslim Other and The Change From Multiculturalism to Assimilation", Master Thesis, Bosphorus University

The Economist, (2016). "A plan for the refugees how to manage the migrant crisis", February 6th 2016.

Ustubici, A. (2011). Turkiye'ye yonelik kadin gocu: seks işcileri ve ev ici hizmetlilerin kişisel guvenlik sorunlarini ilişkilendirmek. Online: 2 Haziran 2017, http://s3.amazonaws.com/academia.edu.documents/30298328/AysenUstubi ci2009kadingocu.pdf?AWSAccessKeyld=AKIAIWOWYYGZ2Y53UL3A\&Expires= 1491508223\&Signature=\%2FeoyiqpmqlbJT1mAxeFGNhdLYZ0\%3D\&responsecontenisposition=inline\%3B\%20filename\%3DTurkiye_ye_yonelik_Kadin_Goc u_Seks_iscil.pdf 
INTERNATIONAL JOURNAL OF ACADEMIC RESEARCH IN BUSINESS AND SOCIAL SCIENCES Vol. 9, No. 9, September, 2019, E-ISSN: $2222-6990$ ๑ 2019 HRMARS

Yilmaz, A. (2014). Uluslarasi goc: ceşitleri, nedenleri ve etkileri. International Periodical for The Languages, Literature and History of Turkish or Turkic, 9(2), 1685-1704. 